\title{
THE STUDY OF CONSUMER BEHAVIOR IN THE MARKET OF BAKERY PRODUCTS IN THE CONDITIONS OF BRAND MANAGEMENT
}

\author{
Hanna Maiboroda'
}

\begin{abstract}
Bread and bakery products are the traditional main component of the Ukrainian market basket. However, in recent years, there has been an annual reduction in the consumption of bakery products. According to the state statistics of Ukraine, the average annual consumption of bread products in 2015 was at the level of $103 \mathrm{~kg}$ per person, while in 2020 this figure was $98 \mathrm{~kg}$ per person. According to experts, one of the main reasons for the decline in this indicator is the decrease in consumer demand. Thus, the study of consumer behavior in the market of bakery products is a very relevant and indispensable issue. The object is the consumer behavior in the market of bakery products. The subject of research is a set of factors that determine consumer behavior in the market of bakery products. Methodology. To study consumer behavior, there was conducted a consumer survey at the oblast level using an external questionnaire with 15 questions to gather the necessary information. Since bread and bakery products are goods of daily and primary demand, the article determines that the general population is the entire population in the region. Their confidence probability is $95 \%$, the confidence interval (error) is $5 \%$, and the sample size was 500 respondents. The questionnaire was compiled using Google Forms software, and survey data were processed using Excel computer software. As a result of research, commodities were reduced, what actual to the consumer in this time, awareness about present brands, factors that induce the consumers of bakery products to render a preference to the separate brand. Nowadays, there is a need to supply the population with quality bakery products of a wide range, as well as those that take into account the consumer's wishes. Manufacturers of bread and bakery products have every opportunity to meet these requirements, and the creation of a strong brand will help ensure the competitiveness of products. Research results may draw on the construction of the future general strategy of the enterprise. They will help in the construction of a strong brand of products for the achievement of competitive edges, an increase of market share, and the general profitability of enterprises.
\end{abstract}

Key words: bakery products, consumer behavior, marketing, brand, brand management, enterprise strategy.

JEL Classification: D12, L66, M31

\section{Introduction}

Development of the world economy and globalization of the consumer market leads to increased competition between producers of similar products. Every entrepreneur seeks to expand their production, increase profitability by entering new markets and attracting more and more consumers. There is a competition not only for markets but also for each customer individually. Therefore, there is a need to study consumer behavior in the market. Knowing and considering the peculiarities of human perception of the product, we can form a positive image (brand), thus giving companies significant competitive advantages. To date, the issue of consumer behavior in the market of bread and bakery products is not

Corresponding author:

${ }^{1}$ Dmytro Motornyi Tavria State Agrotechnological University, Ukraine.

E-mail: annabritsyna@gmail.com

ORCID: https://orcid.org/0000-0002-8190-0259 fully studied in the scientific literature. Hence, there is a need for further study.

The purpose of the article is to substantiate the behavior model of a consumer who buys products from the bakery industry, to study his/her motivation, preferences, factors influencing the purchase of products. These results can be used in the overall strategy of enterprises.

\section{Theoretical foundation}

Many foreign and domestic theorists and practitioners in the field of marketing have been involved in determining consumer behavior in different food markets. In particular, it is necessary to mention the works of O. Yashkina, L. Zakrevska, T. Kulish, S. Bolila, 
N. Buga, T. Fedorova, A. Marchuk, D. Legeza, Y. Sokil, N. Popadynets, A. Konovalenko.

According to O.I. Yashkina (Yashkina, 2018), consumer behavior is a set of aspects (economic, social, psychological) that arise in the process of purchasing products, its use, or transfer of experience to other consumers. L.M. Zakrevska (Zakrevska, 2018) notes that the main task of studying consumer behavior is to identify the influence of psychological factors on the decisions of people, a particular group, or society in general in different economic situations. Modeling consumer behavior for manufacturers allows you to identify the products relevant to the consumer in a given time, the amount of effective demand in the market, awareness of existing brands, factors that have the most impact on the decision to purchase, etc.

\section{Research methodology}

In recent years, the number of small bakeries is rapidly growing, competition in the market is increasing, so manufacturers are focusing their efforts on creating a strong brand. Nowadays, brand loyalty, trust, and commitment to a particular brand are some of the main indicators of business efficiency (Kulish, 2019). The authors conducted a consumer survey at the oblast level for this purpose, using an external questionnaire with 15 questions to gather the necessary information. Since bread and bakery products are goods of daily and primary demand, the article determines that the general population is the entire population in the region. Their confidence probability is $95 \%$, the confidence interval (error) is $5 \%$, and the sample size was 500 respondents. The questionnaire was compiled using Google Forms software, and survey data were processed using Excel computer software.

\section{Finding}

\subsection{General information about bakery product consumers}

The largest number of respondents were women 365 people $(73 \%)$, men $-27 \%$ ( 135 people), i.e., it is women who most often shop and are responsible for food in the family. The age category was the following: $17-25$ years $-24 \%$, 26-45 years $-46 \%$, 46-59 years $25 \%, 60+-6 \%$.

Regarding social status, $77 \%$ of the respondents are the working population (civil servants, entrepreneurs, agricultural workers, social workers, employees), $14 \%$ - students, and only - $9 \%$ - the unemployed (housewives, women on maternity leave, pensioners, or the unemployed). $89 \%$ of respondents live in the city, $11 \%$ live in the village and urban-type settlement.

One of the priority questions in the survey was to determine the place of bread and bakery products in the diet of the population in the region. We know that the demand for bakery products on the market depends on how many bakery products on average a person consumes. The majority of respondents $-55 \%$, consume bakery products every day (69\% of them are women), $43 \%$ - every other day ( $78 \%$ of them are women).

According to the frequency of purchasing products, respondents were distributed as follows: $35 \%$ buy bread and bakery products 1-2 times a week (27\% of them were women, $8 \%$ - men), $33 \%$ - every other day ( $77 \%$ of them women), $20 \%$ - every day ( $64 \%$ of them women), $7 \%$ - buy very rarely. This depends, firstly, on the number of family members, the refusal of a certain category of consumers from flour products due to health and diet indicators. The number of people who start baking bread on their own (5\% of the total number of respondents) also increases (Figure 1).

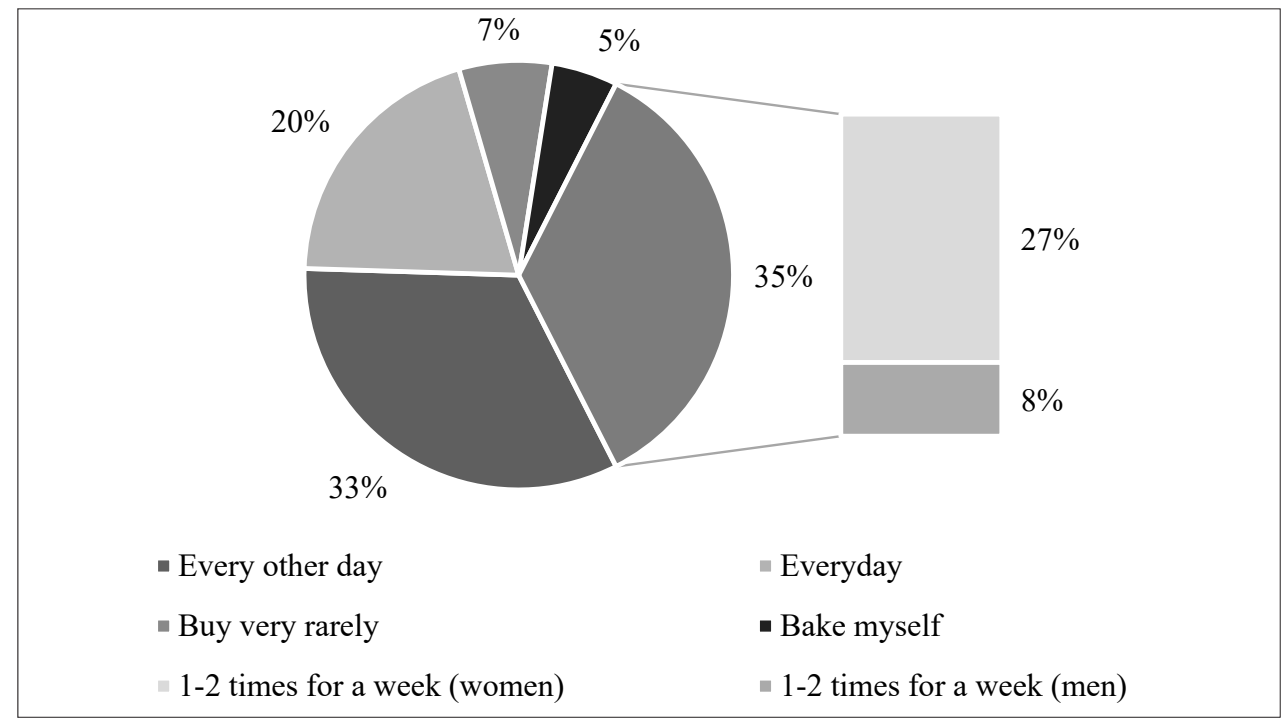

Figure 1. Frequency of acquisition of bakery products, $\%$

Source: author's research 
Of the entire range, consumers prefer bread made from wheat flour $-60 \%$. Rye bread takes second place (32\%), other (alternative) types of bread, increasingly popular among the population, take third place (30\%). They are pita bread, tortilla, ciabatta. Rye-wheat bread ranks fourth in the frequency of purchase among consumers $-23 \% ; 21 \%$ buy bran, whole grain bread. $12 \%$ of the respondents prefer unleavened bread, $10 \%$ of the population buy bread with dried fruits and nuts. There is a certain number of people who do not have special advantages (0.4\%) as well, $0.8 \%$ do not buy bread (they bake it themselves).

\subsection{Consumption of different types of bread in terms of various factors}

The article studies various factors influencing the consumption of different types of bread, such as gender, type of settlement, well-being, and age (Table 1).

Of the total number of respondents, women prefer bread made from wheat flour (27.2\%), other types of bread (such as pita, tortilla, ciabatta) - 16.8\%, rye bread $-16.6 \%$, bran $-12,5 \%$, and rye-wheat $-12 \%$. Men, on the other hand, prefer three types of bread. Almost half of them - $45.7 \%$ - wheat bread, $18.3 \%$ rye bread, $12.9 \%$ - rye-wheat. Other types of bread are not so popular with men. Unlike women, men are more committed to their habits and sometimes do not even think of trying new flavors of bread.

As to the settlement types, the author has found that consumers who live in both urban and rural areas prefer wheat (white) bread (30.9\% and 35.4\%, respectively). Among the rural population, in contrast to the urban population, traditional types of bread, such as rye, rye-wheat, and bran bread, are more popular. The urban population buys more alternative types of bread (pita bread, ciabatta) (respectively in the city - $15.7 \%$, in the village $11.0 \%)$. From the well-being point of view, we see the following tendency: with the increase of consumers' incomes, the level of wheat bread consumption decreases, people prefer healthier "bread" types, such as rye, bran, whole grain, unleavened. In terms of age, there is a tendency to reduce the consumption of wheat bread, and the transition to more useful types. Thus, the amount of rye bread consumption among consumers aged $17-25$ is at the level of $14.8 \%$, in the category "over 60 " it is $17.5 \%$. The consumption of rye-wheat bread has almost doubled (from 10.4\% to $20 \%)$. There is redistribution of consumer preferences in the direction of increasing demand for such types of bread as bran, whole grain, bread with dried fruits. Moreover, alternative types of bread (pita, ciabatta, tortilla) are most in demand in the age category " $26-45$ years".

\subsection{Brand in consumer behavior}

Consumers most often prefer to buy bread and bakery products in branded stores (40\%), in contrast to the number of consumers who most often buy bread and bakery products in stores near the house (19\% of respondents). That is, the brand or branded products of the enterprise are in great demand. Consumers begin to trust the chosen brand, distinguishing it from others, and buy the appropriate brand more often (Legeza, Brunner, Kerimova, Kulish, Konovalenko, 2019).

$26 \%$ of respondents answered the question "how important is it for you to buy a certain brand of bread

Table 1

Distribution of bread consumption in terms of personal consumers characteristics

\begin{tabular}{|c|c|c|c|c|c|c|c|c|c|c|c|}
\hline \multirow[b]{2}{*}{ Bread products } & \multirow{2}{*}{$\begin{array}{l}\text { Gender } \\
\text { Women }\end{array}$} & \multicolumn{3}{|c|}{ Type of settlement } & \multicolumn{3}{|c|}{ Level of well-being } & \multicolumn{4}{|c|}{ Age, years old } \\
\hline & & Men & $\begin{array}{c}\text { Urban } \\
\text { area }\end{array}$ & $\begin{array}{c}\text { Rural } \\
\text { area }\end{array}$ & Low & Average & High & $17-25$ age & $26-45$ age & 46-59 age & over 60 \\
\hline Wheat bread & 27.2 & 45.7 & 30.9 & 35.4 & 40.2 & 39.1 & 37.4 & 44.5 & 28.9 & 24.8 & 17.5 \\
\hline Rye bread & 16.6 & 18.3 & 16.7 & 19.5 & 15.1 & 16.2 & 15.4 & 14.8 & 16.8 & 19.1 & 17.5 \\
\hline Rye-wheat bread & 12.0 & 12.9 & 12.0 & 13.4 & 13 & 13.5 & 14.3 & 10.4 & 11.6 & 13.5 & 20.0 \\
\hline Bran (whole grain) bread & 12.5 & 4.8 & 10.5 & 12.2 & 11.4 & 12.1 & 12.6 & 9.3 & 10.7 & 9.9 & 17.5 \\
\hline $\begin{array}{l}\text { Other types (pita, } \\
\text { tortilla, ciabatta) }\end{array}$ & 16.8 & 10.2 & 15.7 & 11.0 & 9.3 & 8.4 & 9.9 & 13.7 & 17.3 & 11.3 & 10 \\
\hline Unleavened bread & 7.0 & 3.2 & 6.7 & 1.2 & 8 & 9.3 & 9.7 & 1.6 & 7 & 9.2 & 5.0 \\
\hline $\begin{array}{l}\text { Bread from other types } \\
\text { of flour (corn, rice) }\end{array}$ & 1.1 & 1.1 & 1.1 & 1.2 & 0.1 & 0.1 & 0.1 & - & 1.5 & 1.4 & - \\
\hline $\begin{array}{l}\text { Bread with dried fruit, } \\
\text { nuts, seed }\end{array}$ & 6.2 & 3.2 & 5.5 & 6.1 & 2.3 & 1.3 & 0.6 & 5.5 & 5.3 & 5.7 & 7.5 \\
\hline $\begin{array}{l}\text { There are not the special } \\
\text { advantages }\end{array}$ & 0.3 & 0.5 & 0.4 & - & 0.1 & - & - & - & 0.9 & 1.4 & 2.5 \\
\hline $\begin{array}{l}\text { Does not buy bread } \\
\text { (bake) }\end{array}$ & 0.3 & - & 0.4 & - & 0.5 & - & - & - & - & 3.5 & - \\
\hline
\end{tabular}

Source: author's research 
and bakery products" as very important, I always choose products of a certain brand; $37 \%$ of respondents important, but sometimes other factors influence the purchase at the moment; $24 \%$ of respondents - equally important and unimportant; $13 \%$ of respondents say that they do not mind buying products from different manufacturers and different brands.

According to the respondents, high-quality bakery products need advertising. When buying products, 33\% of respondents mainly rely on the advice of relatives and friends, $20 \%$ - on local television, $18 \%$ - outdoor advertising, $15 \%$ - print media, $12 \%$ - exhibitions and fairs.

In the study of consumer preferences, we give the respondents 10 main criteria that influence the decision to purchase bakery products. They are taste, quality, price, product appearance, product weight, packaging (design), date of manufacture and expiration date, the manufacturer (separate brand), composition and useful substances, and form of the product. The task was to prioritize these criteria from 1 to 10 , where 1 is not important, 10 - pay maximum attention when making a purchase decision (Figure 2).

During the survey, the author determined the most important factors for consumers of bread and bakery products. The indicators are: "product quality" (94\%), "taste characteristics" (83\%), "manufacturer (individual brand)" (79\%), "date of manufacture and expiration date” (74\%), "packaging (design)” (70\%). Category "price" - takes 6th place (61\%), and then, in descending order: "appearance of the product" (40\%), "composition and nutrients" (32\%), "product weight" (21\%)) and, finally, consumers pay attention to the shape of the product (13\%). That is, when making a purchase decision, consumers of bakery products pay more attention to non-price factors (taste, quality, brand, packaging) than the price factor.

\subsection{The model of consumer behavior of the bakery products}

Table 2

The model of consumer behavior of the bakery products

\begin{tabular}{|c|l|c|}
\hline № & \multicolumn{1}{|c|}{ Criteria } & Respondents, \% \\
\hline 1 & \multicolumn{1}{|c|}{2} & 3 \\
\hline \multirow{4}{*}{1.} & Gender: & \\
& - men; & 27 \\
& - women. & 73 \\
\hline \multirow{4}{*}{2.} & Age, years old: & \\
& - 17-25 age; & 24 \\
& $-26-45$ age; & 46 \\
& - 46-59 age; & 25 \\
& - over 60. & 6 \\
\hline
\end{tabular}

(Continuation of Table 2)

\begin{tabular}{|c|c|c|}
\hline 1 & 2 & 3 \\
\hline 3. & $\begin{array}{l}\text { Social status: } \\
\text { - employee; } \\
\text { - state employee; } \\
\text { - employer; } \\
\text { - student; } \\
\text { - unemployed; } \\
\text { - retired; } \\
\text { - others. }\end{array}$ & $\begin{array}{c}57 \\
12 \\
8 \\
14 \\
3 \\
2 \\
4\end{array}$ \\
\hline 4. & $\begin{array}{l}\text { Number of family members: } \\
-1 \text { person; } \\
-2 \text { people; } \\
\text { - } 3 \text { people; } \\
-4 \text { people; } \\
-5 \text { and more. }\end{array}$ & $\begin{array}{c}4 \\
19 \\
34 \\
27 \\
16\end{array}$ \\
\hline 5. & $\begin{array}{l}\text { Residence: } \\
\text { - city; } \\
\text { - village; } \\
\text { - urban-type settlement. }\end{array}$ & $\begin{array}{c}89 \\
3 \\
8\end{array}$ \\
\hline 6. & $\begin{array}{l}\text { Level of well-being: } \\
\text { - low; } \\
\text { - average; } \\
\text { - high. }\end{array}$ & $\begin{array}{l}25 \\
64 \\
11\end{array}$ \\
\hline 7. & $\begin{array}{l}\text { Frequency of acquisition } \\
\text { of bakery products: } \\
\text { - everyday; } \\
\text { - every other day; } \\
\text { - 1-2 times for a week; } \\
\text { - buy very rarely; } \\
\text { - bake myself. }\end{array}$ & $\begin{array}{c}20 \\
33 \\
35 \\
7 \\
5\end{array}$ \\
\hline . & $\begin{array}{l}\text { Consumer factors that influence } \\
\text { the purchase (\%): } \\
\text { - Product quality; } \\
\text { - Taste characteristics; } \\
\text { - Manufacturer (individual brand); } \\
\text { - Date of manufacture and expiration } \\
\text { date; } \\
\text { - Packaging; } \\
\text { - Price; } \\
\text { - Appearance of the product; } \\
\text { - Composition and nutrients; } \\
\text { - Product weight; } \\
\text { - Shape of the product. }\end{array}$ & $\begin{array}{l}74 \\
70 \\
61 \\
40 \\
32 \\
21 \\
13\end{array}$ \\
\hline
\end{tabular}

Source: author's research

The behavior model of a consumer of the bakery industry is an employed woman 26 to 45 years old, who has a family of 3-4 members and lives in the city with an average well-being level. She buys bread or bakery products mainly 1-3 times a week. As for the preferences, she buys wheat bread and bakery products most often. She has requirements for the product in terms of quality, taste, date of manufacture and expiration date, availability, and functionality of packaging. 


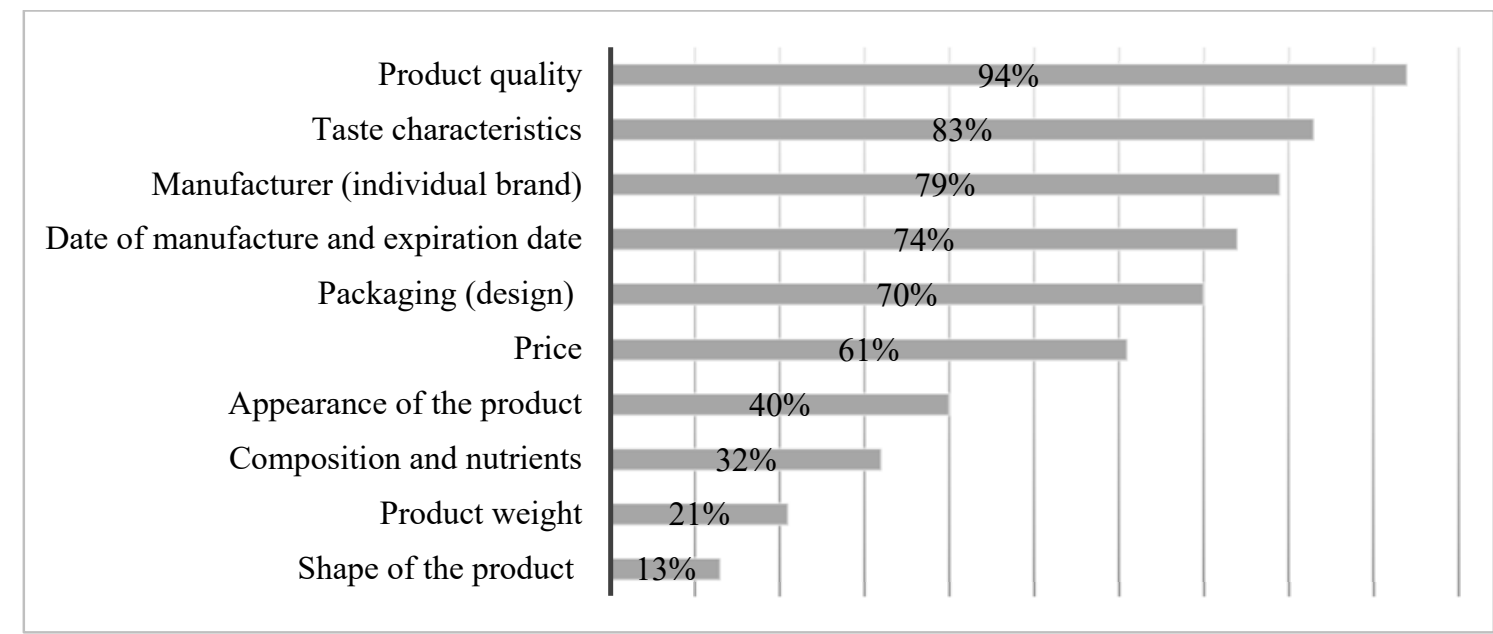

Figure 2. Rating of factors that influence the purchase of bread and bakery products

Source: author's research

\section{Conclusions}

Bread and bakery products are foods of permanent demand that are included in a market basket by practically everyone. But recently, there has been a reduction in the amount of consumption of bakery products. At the same time, the number of producers of these products is growing, there is a large number of small businesses (mini-bakeries), which are beginning to compete with large bakeries.

To hold out in the market, manufacturers needed to pay great attention to the study of consumer behavior, using the results obtained in the formation of a strong brand, and in the future - for the overall strategy of the enterprise. With the help of the conducted research, the results of which are covered in this article, a model of consumer behavior of bakery products was compiled and the following results were obtained.

1. The largest number of respondents were women 365 people ( $73 \%)$, men $-27 \%$ ( 135 people), i.e., it is women who most often shop and are responsible for food in the family.

2. The majority of respondents consume bakery products every day or every other day. However, according to the frequency of purchasing products, a larger number of respondents answered that they buy bread and bakery products 1-2 times a week or every other day.
3. Of the entire range, consumers give the greatest preference to bread made from wheat flour, rye bread, and such types of bakery products as pita, tortilla, ciabatta. At the same time, the urban population gives more preference to wheat bread and alternative types of bakery products, and the rural population - rye, ryewheat, bran bread.

4. Consumers most often prefer to buy bread and bakery products in branded stores. A larger number of respondents noted that a certain manufacturer or brand is important for them when buying. That is, the brand or branded products of the enterprise are in great demand. Consumers begin to trust the chosen brand, distinguishing it from others, and buy the appropriate brand more often.

5. When making a purchase decision, consumers of bakery products pay more attention to non-price factors (taste, quality, brand, packaging) than the price factor.

Therefore, in modern market conditions, there is a need to supply the population with quality bakery products of a wide range, as well as those that take into account the consumer wishes. Manufacturers of bread and bakery products have every opportunity to meet these requirements, and the creation of a strong brand will help ensure the competitiveness of products.

\section{References:}

Bolila, S. Y., \& Fedorova, T. V. (2018). Profil spozhyvacha yak osnova dlia pryiniattia marketynhovykh rishen pidpryiemstvom khlibopekarskoi haluzi [Consumer profile as a basis for marketing decisions by the bakery company]. Business navigator, vol. 4, no. 47, pp. 61-65.

Buga, N. V., \& Antonenko, O. Y. (2014). Marketynhova stratehiia v vyrobnytstvi i prosuvanni khlibobulochnoi produktsii (na prykladi Kyivskoho rehionalnoho rynku) [Marketing strategy in the production and promotion of bakery products (on the example of the Kyiv regional market)]. Efficient economy, no. 11. Available at: http://www.economy.nayka.com.ua/?op=1\&z=3498 (accessed July 1, 2021).

Kulish, T. V. (2019). Marketynhove doslidzhennia povedinky spozhyvachiv na rynku plodovo-yahidnoi produktsii [Marketing research of consumer behavior in the market of fruit and berry products]. Collection of scientific works of 
Dmytro Motornyi Tavria State Agrotechnological University (economic sciences), vol. 1, no. 39, pp. 72-79. Available at: http://elar.tsatu.edu.ua/handle/123456789/10412 (accessed July 1, 2021).

Legeza, D., Brunner, T., Kerimova, Y., Kulish, T., \& Konovalenko, A. A (2019). A model of consumer buying behavior in relation to eco-intelligent products in catering. Innovative Marketing, vol. 1, no. 15, pp. 54-65. Available at: http://elar.tsatu.edu.ua/handle/123456789/12758 (accessed July 1, 2021).

Marchuk, A. O. Osoblyvosti formuvannia modeli povedinky spozhyvachiv dytiachoi molochnoi produktsii [Features of formation of model of behavior of consumers of children's dairy products]. Collection of scientific works of Dmytro Motornyi Tavria State Agrotechnological University (economic sciences), vol. 1, no. 43, pp. 166-174. Available at: https://inlnk.ru/qVy6M (accessed July 1, 2021).

Popadynets, N. M. (2017). Osoblyvosti spozhyvchoi povedinky naselennia Ukrainy ta krain-chleniv Yevropeiskoho Soiuzu [Features of consumer behavior of the population of Ukraine and the member states of the European Union]. Economics and management of the national economy, vol. 5, no. 127, pp. 9-14.

Shkvirya, N. O. (2019). Marketynhovi doslidzhennia spozhyvchykh perevah na rynku khliba ta khlibobulochnykh vyrobiv [Marketing research of consumer preferences in the market of bread and bakery products]. Collection of materials of the international scientific-practical Internet conference of students, graduate students: Innovative development and safety of enterprises in a neo-industrial society (October 31, 2019) pp. 715-717. Available at: http://elar.tsatu.edu.ua/handle/123456789/8913 (accessed July 1, 2021).

Shkvirya, N. O., \& Sokil, Y. S. (2015). Marketynhove doslidzhennia povedinky spozhyvachiv na rynku sokiv [Marketing research of consumer behavior in the juice market]. Proceedings of the III international scientific-practical conference: Marketing education in Ukraine (April 12-13, 2015), pp. 341-349. Available at: https://ir.kneu.edu.ua/bitstream/handle/2010/19314/341-349.pdf? sequence=1 (accessed July 1, 2021).

Yashkina, O. I. (2018). Marketynhovi doslidzhennya spozhyvachiv dlya vdoskonalennya smakovykh yakostey vyna [Consumer marketing research to improve the taste of wine]. Marketing and Digital Technologies, vol. 2, no. 4, pp. 80-93.

Zakrevska, L. M. (2018). Povedinkova ekonomika yak instrument zabezpechennia stalykh konkurentnykh perevah [Behavioral economics as a tool to ensure sustainable competitive advantage]. Scientific works of the National University of Food Technologies, vol. 24, no. 3, pp. 55-61. DOI: 